\title{
"PRECIOUS": \\ A TALE OF THREE EXPLANATIONS FOR CHILDHOOD MALTREATMENT
}

\author{
Reginald Leamon Robinson ${ }^{*}$
}

\section{INTRODUCTION}

Precious describes a fictional child's life, in which the parents severely maltreat her. ${ }^{1}$ Historically, society gave parents the right to assault their children's bodies, ${ }^{2}$ if those assaults were not abuse but discipline. ${ }^{3}$ Traditionally, constitutional analysis enshrined those

* Professor of Law, Howard University School of Law, Washington, D.C. I wish to thank Professor Anthony Farley for inviting me to participate in this project on CRT and Marxism. I would also like to thank Professor Kimberly Alderman (Wisconsin), Dean Peter Alexander (Indiana Tech), Sylvia Ellison, Alexandra Kedrock, LCSW, Professor Cheryl LaRouche (George Washington), Professor Alice Noble-Allgire (SIU), and Professor Victor Romero (Penn State) for their support, read, and constructive feedback. I would especially like to thank Professor Lenese Herbert (Albany, Visiting Howard 2012-2013) not only for her very close read but also for our four-day talk about the Essay and its personal and social implications.

1 See generally SAPPHIRE, PUSH: A NOVEL (1996) [hereinafter SAPPHIRE]; PRECIOUS (Lionsgate 2009) (a story about how a young girl abused by her mother and father who overcomes adversity).

2 See, e.g., Johnson v. State, 1840 WL 1574, at *1 (Tenn. Dec. 1840) Judge Turley states, "[t]he right of parents to chastise their refractory and disobedient children is so necessary to the government of families, to the good order of society, that no moralist or lawgiver has ever thought of interfering with its existence, or of calling upon them to account for the manner of its exercise, upon light or frivolous pretences.").

3 See, e.g., Hinkle v. State, 26 N.E. 777, 778 (Ind. 1891) (Chief Judge Olds states, "Parents bringing children into the world owe to them and to the community the duty of caring for and properly training them in infancy, and curbing the evil tendencies at a time and at an age when it can be done without resorting to excessive punishment and cruel and inhuman treatment[.]"). Even today, some advocates for ending corporal punishment have so deeply internalized the right of parents to use violence against their children as part of proper child-rearing practices that they mentally uncoupled the impact of corporal punishment from its damage not only to children but also the 
rights, ${ }^{4}$ and parents had autonomy to rear and discipline their children as they saw fit. ${ }^{5}$ Unfortunately, when parents abused their children and were prosecuted, ${ }^{6}$ few exculpatory and justificatory explanations were offered. ${ }^{7}$ Today, we know that parents who abuse have suffered abuse, too. ${ }^{8}$ Hence, Precious' parents'

consequential cost to society. See Murray A. Straus with Denise A. Donnelly, Beating the Devil Out of Them: Corporal Punishment IN AMERICAN FAMILIES AND ITS EFFECTS ON CHILDREN, at iv (2001) [hereinafter STRAUS WITH DONNELLY] (in response to a reporter's question "on whether parents should prohibited from spanking, [the director of an organization devoted to ending corporal punishment in schools] said a few swats on the rear by loving parents is nothing to worry about.").

4 See generally Meyer v. Nebraska, 262 U.S. 390, 399 (1923) (The Fourteenth Amendment's liberty interest "denotes ... the right . . . to . . . establish a home and bring up children."); Pierce v. Society of Sisters, 268 U.S. 510, 534 (1925) (Under Meyer, "the Act of 1922 unreasonably interferes with the liberty of parents and guardians to direct the upbringing and education of children under their control.").

5 See, e.g., Roe v. Doe, 272 N.E.2d 567, 570 (N.Y. 1971) ("It is the natural right, as well as the legal duty, of a parent to care for, control and protect his child from potential harm, whatever the source and absent a clear showing of misfeasance, abuse or neglect, courts should not interfere with that delicate responsibility.”).

6 See, e.g., People v. Karen P., 692 N.E.2d 338 (Ill. App. 1998) (reversing a lower court and ruling that mother's frequent use of wooden spoon to spank child was not excessive corporal punishment); In Re Ethan H., 609 A.2d 1222 (N.H. 1992) (lower court finding that mother abused her sevenyear old child by spanking her with a belt, which caused bruises, was not supported by the evidence); State v. Kaimimoku, 841 P.2d 1076 (Haw. App. 1992) (court reversing lower court's conviction of abuse of family and household members because state failed to disprove that father's use of force against daughter was justifiable discipline of a minor child).

7 See, e.g., People v. Karen P., 692 N.E.2d at 339 (Karen explained to an agent for the Department of Children and Family Services that after attending parenting classes and receiving teachings at her church, "she believed it was wrong to hit with the hand because the hand represents love. Therefore, it was better ... to use an object such as the wooden spoon, instead of the hand, to discipline.").

8 See STRAus WITH Donnelly, supra note 3, at xix (Parents "do not realize the harmful side effects of corporal punishment because those effects do not show up until later in life. When a parent spanks a child, there is no obvious clue to signal that this is increasing the chance that the child will grow up to beat his wife, physically abuse her children, or suffer from mental illness or other social and psychological ills."). See also JOHN HEAD, BLACK MEN and Depression: SAVING OUR Lives, Healing Our FAmilies and FRIENDS 1-27, 28-53 (2004) (devoting four paragraphs to his childhood upbringing by a single mother who divorced his father when he was four years old, Head faults not childhood maltreatment but American slavery and racism 
childhood histories help to explain her maltreatment and reveal the best framework for the etiology of her horrific suffering. ${ }^{9}$

This Essay proffers three explanations: Critical Race Theory's (CRT) race consciousness, Karl Marx' alienation theory, and Alice Miller's psycho-existential framework. Each approach may explain why parents maltreat their children. In brief, CRT and alienation theories operate at structural levels, well above the intergenerational transfer of actual suffering from parent to child. To be sure, structuralist theories may explain why black children like Precious suffered horrific maltreatment not by faulting the parents but by pointing to external, objective forces like white racism. ${ }^{10}$ CRT begins by analyzing slavery, Jim Crow, and the breakdown of the black family. ${ }^{11}$ Marxism likewise starts by critiquing an economic world in which capitalism's slavery exploited workers and black slaves. $^{12}$ Yet, violent, physical assaults against children predate

for the chronic depression among black men within the black community, saying, "America's failure to address the damage that depression does to African American men is rooted, in part, in prejudice and stigma that date all the way back to the docking of that first slave ship").

9 See, e.g., Kealan Oliver, 9-Year-Old Says "Ex-Mom" Renee Bowman Murdered Step-Sisters, Kept Bodies in Freezer, CBS NEWS, Feb. 18, 2010, http://www.cbsnews.com/8301-504083_162-6217712-504083.html ("The girl said Bowman repeatedly beat her and her sisters with a baseball bat and a shoe. She also stated she was beaten the worst on 'the back part and the front part,' using her teddy bear to demonstrate where she was hit. She pointed to its backside and its crotch.").

10 See Alice Miller, Banished KnOWLedge: FACING CHILdHOOd InJuRIES 33 (Leila Vennewitz trans., 1990) (1988) [hereinafter MiLLER, BANISHED KNOWLEDGE] ("A black psychology student in a group in London once told me, 'From the very beginning I was physically, psychically, and sexually abused'... 'Our parents claim to have learned cruelty from whites and deny their own parents' contribution.' ').

11 See, e.g., Adrian Wing \& Laura Wesselman, Transcending Traditional Notions of Mothering: The Need for Critical Race Feminist Praxis, 3 J. GENDER RACE \& JUST. 257, 262 (1999) (in arguing against the white essentialist, ideal mother, which displaces the black women as proper, these authors begin with slavery as the source of this displacement and argue for Patricia Hill Collin's "othermothering", which includes a broad range of non-white potential caregivers).

12 See Karl Marx, CAPital: A Critical Analysis of Capitalist PRODUCTION 759-60 (Frederick Engels ed., 1977) (1887) ("Whilst the cotton industry introduced child-slavery in England, it gave in the United States a stimulus to the transformation of the earlier, more or less patriarchcal slavery, into a system of commercial exploitation. In fact, the veiled slavery of the wage-workers in Europe needed, for its pedestal, slavery pure and simple in the new world."). 
American Negro slavery and modern capitalism, ${ }^{13}$ which mean that neither of them would completely and persuasively explain childhood maltreatment. And neither approach takes us beyond believing that external, objective forces have constructed our abusive imaginations, ${ }^{14}$ which are enforced by the hegemonic workings ${ }^{15}$ of powerful whites and white structural oppression. ${ }^{16}$

Unlike these approaches, Miller's framework existentially and interpersonally accounts for Carl Jones and Mary Johnston's use of "poisonous pedagogy"17 to rear and maltreat Precious. Accordingly, Precious' parents' own repressed trauma becomes the prime mover in her maltreatment, the darkness of which is often covered symbolically and legally by the parents' legal right to beat

13 See generally Mason P. Thomas, Jr., Child Abuse and Neglect, Part I: Historical Overview, Legal Matrix, and Social Perspectives, 50 N.C. L. REV. 293, 295 ("Under ancient Roman law the father had a power of life and death (patria potestas) over his children that extended into adulthood. He could kill, mutilate, sell, or offer his child in sacrifice. While infanticide was not common in Rome, exposure was widespread.”).

${ }^{14}$ Cf. Robert W. Gordon, Unfreezing Legal Reality: Critical Approaches to Law, 15 FLA. ST. U. L. REV. 195, 198 (1987) ("ordinary discourses of law . . all contribute to cementing this feeling, at once despairing and complacent, that things must be the way they are and that major changes could only make them worse").

15 See, e.g., Robert W. Gordon, New Developments in Legal Theory, in The Politics of Law: A Progressive Critique 413, 418 (David Kairys ed., 1982) (citing Antonio Gramsci's notion of hegemony who argued "that the most effective kind of domination takes place when both the dominant and dominated classes believe that the existing order, with perhaps some marginal changes, is satisfactory, or at least represents the most that anyone could expect, because things pretty much have to be the way they are"); Kimberlé Williams Crenshaw, Race, Reform, and Retrenchment: Transformation and Legitimation of Antidiscrimination Law, 101 HARV. L. REV. 1331, 1351 (1988) [hereinafter Crenshaw, Race, Reform, and Retrenchment] ("The concept of hegemony allows Critical scholars to explain the continued legitimacy of American society by revealing how legal consciousness induces people to accept or consent to their own oppression.”).

16 See Reginald Leamon Robinson, Human Agency, Negated Subjectivity, and White Structural Oppression: An Analysis of Critical Race Practice/Praxis, 53 AM. U. L. REV. 1361, 1363 (2004) [hereinafter Robinson, Human Agency] ("Within a broad structuralist framework, white structural oppression refers to practices like racism that constitute an objective, external power that robs people of their natural right to be free human beings.”).

17 See generally Alice Miller, For Your Own GoOd: HidDen CRUelty in ChILD-ReARING AND THE RoOTS OF Violence (Hildegarde Hannum \& Hunter Hannum trans., 4th ed. 2002) (1980) [hereinafter MiLler, FOR YOUR OWN GOOD] (analyzing the maltreatment effects of education and child rearing on children through the "pedagogical approach"). 
their children. ${ }^{18}$ This Essay argues that unlike CRT and alienation theory, Miller's psycho-existentialism best explains Precious' dire experiences because it accounts for Carl and Mary's more than certain abusive childhood experiences, it links Mary's abusive experiences to her use of withering obedience training, and it helps us connect Mary's repressed authentic feelings ${ }^{19}$ to the need to maltreat her own child.

Part I provides an overview of Precious and some specific maltreated experiences that Precious suffers. Part II applies CRT's race consciousness premise, Marx's alienation theory, and Miller's psycho-existentialism, and concludes that psycho-existentialism best explains Precious' severe maltreatment. Psycho-existentialism explains the violent forces that impacted Precious were not the present effects of past discrimination, modern discrimination, or the disfiguring class oppression of workers under evolving capitalism. Against these so-called external, impersonal, and objective forces, psycho-existentialism posits that Carl and Mary's inability to access their own repressed childhood trauma-which through "emotional blindness" 20 unconsciously urged them to abuse Precious directly or by proxy-caused what they did to her. ${ }^{21}$ Finally, Part III serves as the Essay's conclusion.

18 See generally Chronister v. Brennenman, 742 A.2d 190 (Pa. 1999) (overturning a order of protection against a father who hit his daughter four or five times on the buttocks because she lied to him, holding that such discipline or punishment did not constitute abuse within the meaning of the Protection From Abuse Act); LEON SHELEFF, GENERATIONS APART: AdUlt HOSTILITY TO YOUTH (1981) (arguing that Freud and neo-Freudian scholars use the Oedipus complex to perhaps unconsciously depict power implications of fathers killing their children, primarily sons, because it permitted them to repress the obviousness of parents warring against their children). See also infra notes 150-151 (discussing and applying Alice Miller's psycho-existential framework to Precious).

19 See Miller, Banished KNOWLedge, supra note 10 , at 2 (suggesting that a child's authentic feelings start in infancy, "he relies entirely on those around him to hear his cries .... The only possible recourse a baby has when his screams are ignored is to repress his distress, which is tantamount to mutilating his soul, for the result is an interference with his ability to feel, to be aware, and to remember").

20 See id. at 37 (Emotional blindness "is the consequence of a repression of feelings and memories that renders a person unable to see certain sets of circumstances.").

${ }^{21} I d$. at 2-3 ("[Maltreated parents] will not remember the torments to which they were once exposed, because those torments, together will the needs related to them, have all been repressed: that is, completely banished from consciousness."). 


\title{
I. Precious and Mary's Obedience Training
}

\author{
The evidence is ever more conclusive that $C P$ \\ [corporal punishment] is counterproductive \\ and has harmful psychological effects. ${ }^{22}$
}

\section{A. A Brief Overview}

In Precious, Carl and Mary severely maltreated their child by raping, assaulting, and humiliating Precious. ${ }^{23}$ Mary further exposed Precious to physical ${ }^{24}$ and emotional harm ${ }^{25}$ by failing to protect her. After Precious had her first child by Carl at age twelve, ${ }^{26}$ Carl abandoned the family. ${ }^{27}$ However, before his death, ${ }^{28}$ Mary took her daughter to her pedophiliac father, thus further exposing her child to harm and to his carnal depravity. ${ }^{29}$

22 STRAUS WITH DONNELLY, supra note 3, at xv.

23 See generally SAPPHIRE, supra note 1. Shortly after Precious has her first child, the nurses collect data on her mother, her father, and the baby's father. " 'Father,' she say. 'What's your daddy's name?' 'Carl Kenwood Jones, born in the Bronx.' She say, 'What's the baby's father's name?' I say, 'Carl Kenwood Jones, born in the same Bronx.' "Id. at 12.

24 See Diana J. English, The Extent and Consequences of Child Maltreatment, 8 THE FUTURE OF CHILDREN 39, 41 (1998) (defining physical abuse as "An act of commission by a caregiver that results or is likely to result in physical harm, including death of a child. Examples of physical abuse acts include kicking, biting, shaking, stabbing, or punching of a child. Spanking a child is usually considered a disciplinary action, although it can be classified as abusive if the child is bruised or injured").

${ }^{25} \mathrm{Id}$. at 41 (defining emotional harm as "[a]n act of commission or omission that includes rejecting, isolating, terrorizing, ignoring, or corrupting a child. Examples of emotional abuse are confinement; verbal abuse; withholding sleep, food, or shelter; exposing a child to domestic violence; allowing a child to engage in substance abuse or criminal activity; refusing to provide psychological care; and other inattention that results in harm or potential harm to a child. An important component of emotional or psychological abuse is that it must be sustained and repetitive.").

26 SAPPHIRE, supra note 1 , at 12 .

27 Id. at $19-20$.

${ }^{28} \mathrm{Id}$. at 87 ("'Your daddy dead' . . So what! I'm glad the nigger's dead. No, I don't mean that, but so what. Mama quiet. Mama say, 'Carl had the AIDS virus.' ").

${ }^{29}$ Id. at 25-26 ("She bring him to me. I ain' crazy, that stinky hoe give me to him. Thas' what he require to fuck her probably, some of me."). 
By sixteen, Precious' dark, brutal world began to implode, perhaps for the best. She was pregnant with Carl's second child. ${ }^{30}$ Discovering her pregnancy, a white school administrator required her to attend alternative educational program, "Each One Teach One."31 At this program, Precious realized that she no longer needed to be Mary's exploited slave. ${ }^{32}$ Precious also experienced growth, learned to read, began to trust in others, ${ }^{33}$ struggled with self-denial, ${ }^{34}$ and embraced a life as a devoted mother, 35 in which she would not suffer Mary's maltreatment. ${ }^{36}$

${ }^{30} I d$. at 10 (The EMS officer who helped Precious deliver her child said, "Precious, it's almost here. I want you to push, you hear me momi, when that shit hit you again, go with it and push, Preshecita. Push.'").

${ }^{31} I d$. at 6-8, 15-16 (Once her teachers and administrators recognized that she was pregnant, they required her to leave the high school and to attend the Alternative Program. Initially, Precious cannot understand why she's forced to leave, believing that she'd done nothing, and that her grades were good.).

${ }^{32}$ Id. at 64 (After attending the "Each One Teach One" Program for a month, Precious realized that she was not invisible anyone, unlike her experience at home when she is living with her mother); $i d$. at 66 (Precious believed Mary would have killed her if she'd not be receiving a welfare check for her daughter and her first son).

${ }^{33} I d$. at 139. Precious was headed to a Body Positive meeting, and she needed "Miz Mom" to watch Abdul. Miz Mom gave Precious until 6:30 pm to go and come back, and she offered Precious three dollars, which caused a slight inner psyche break within her because Precious realized that adult maternal figures can treat her with love, kindness, and respect. Precious thinks, "Something tear inside me. I wanna cry but I can't. It's like something inside me keeps ripping but I can't cry. I think how alive I am, every part of me that is cells, proteens, neutrons, hairs, pussy, eyeballs, nervus sistem, brain. I got poems, a son, friends. I want to live so bad."

34 See, e.g., id. at 115-16 (In response to Ms. Rain's request to have Precious and others write down their fantasies if life were perfect, Precious reveals her first of three perfect worlds: "I would be light skinned, thereby treated right and loved by boyz. Light even more important than being skinny; you see them light-skinned girls that's big an' fat, they got boyfriends. Boyz overlook a lot to be wif a white girl or yellow girl, especially if it's a boy that's dark skin wif big lips or nose, he will go APE over yellow girl.”).

35 Id. at 120-21 (Precious reads from file, in which Ms. Weiss makes observations about her generally and about her commitment to parenting her second son, Abdul. Ms. Weiss writes: "Precious attends to his needs a-s-s-i-du-o-s-l-y (whatever!) and with great affection and ee-" (“'Eagerly," " Jermaine say) " "seeks any and all information on child rearing. (I guess so I'm his mother!) '”).

${ }^{36}$ Id. at 119 (Ms. Weiss states, "You know your mother's been calling here wanting to come visit.' " And Precious responds, " 'No, I didn't know that." " Ms. Weiss replies, "Would you like to have her come into a 
Despite her growth, Precious still did not know why she had suffered maltreatment. ${ }^{37}$ Without knowing, Precious would continue to repress the pain of her parents' betrayal. Unfortunately, repression will not stave off Precious' anger, which eventually will affect everyone and everything around her. ${ }^{38}$ For example, Mary's repressed childhood history more than likely accounted for her horrific maltreatment of Precious. ${ }^{39}$ As such, Precious likewise could impose her trauma on her two children. ${ }^{40}$ Nevertheless, after leaving Mary, Precious did excel. ${ }^{41}$ Unfortunately, excelling and reading will not, without more, help Precious to access her lost childhood history and to truly overcome what Carl and Mary did to her.

counseling session with you?” " Precious responds back, "'I don't know, I never think about it before." ").

37 See Alice Miller, Free From Lies: Discovering Your True NeEds 11 (Andrew Jenkins trans., 2007) [hereinafter MILLER, FreE FroM LIES]. On this point, Miller states:

$\Pi \mathrm{n}$ adulthood, the combination of infant confusion and the denial of suffering obviously instills reluctance or downright refusal to reflect on the problem posed by inflicting physical punishment on small children. Mental blockades (and the fear underlying them) prevent us from asking ourselves how this confusion originated in the first place. Accordingly, we fend off everything that would lead to such reflection.

Id. (emphasis added).

38 See, e.g., SAPPHIRE, supra note 1, at 4. Precious obviously responded to a stressful, perhaps embarrassing moment, especially because she wanted to hide that she could not read, with anger. On the first day of math class, her teacher says, "'[c]lass turn the book pages to page 122 please.' I don't move. He say, 'Miss Jones, I said turn the book pages to page 122.' I say, 'Mutherfucker I ain't deaf?' The whole class laugh. He turn red. He slam his han' down on the book and say, 'Try to have some discipline.' He a skinny little white man about five feets four inches. A peckerwood as my mother would say." Id.; $i d$. at 5 ("I didn't want to hurt him or embarrass him like that you know. But I couldn't let him, anybody, know, page 122 look like page 152, 22, 3, 6, 5-all the pages look alike to me.”).

39 See Miller, Banished KnOwledge, supra note 10, at 4 ("And later, as adults, they had themselves forgotten such experiences .... But somehow they must have known, their brains had obviously stored the knowledge, for in a sort of compulsive repetition they passed on their traumatic experiences to their children, again oblivious to the consequences.").

$40 \mathrm{Id}$.

41 See SAPPHIRE, supra note 1, at 120 (Ms. Weiss states that Precious made great strides in the past year, thus receiving the "mayor's award for outstanding achievement."). 
At "Each One Teach One," Precious needed an "enlightened witness," 42 who would tell her directly that Carl and Mary were wrong to maltreat her. Her teacher, Ms. Rain, encouraged her with positive feedback, helping her to understand that institutional markers like reading scores cannot determine her future. ${ }^{43}$ Her social worker, Ms. Weiss, wanted her to access memories of her parents, ${ }^{44}$ without telling Precious that her childhood history, however traumatic, would promote healing by faulting her parents. 45 Accordingly, her teacher and social worker were not "potential helpers." 46 Even if Precious could appreciate the impact of white racism or answer questions about her memories of her parents, Precious would still fault whites, who would serve as

42 Alice Miller, The Truth Will Set You Free: Overcoming Emotional Blindness and Finding Your True Adult SElF, at $\mathrm{x}$-xi (Andrew Jenkins trans., 2001) ("In adult life, a role similar to that of childhood's helping witness may be taken over by an enlightened witness. By this I mean someone who is aware of the consequences that neglect and cruelty in childhood can have. Enlightened witnesses support these harmed individuals, empathize with them, and help them gain an understanding of their feelings of anxiety and powerlessness as products of their own history rather than as some frightening, mysterious force.”).

43 SAPPHIRE, supra note 1 , at 110 . In response to Precious saying that she has a 2.8 score, Ms. Rain says, “it's a number! And can't no numbers measure how fair I done come in jus' two years. She say forget about the numbers and just keep working. . . . Don't worry about numbers and fill in the blank, just read and write!" Id.

${ }^{44}$ Id. at 117-19 (Ms. Weiss asked Precious about the first memories of her mother).

45 See Miller, Banished KNOWledge, supra note 10, at 28-29. Miller describes therapy that helps clients feel their anger:

First, through reawakened feelings, he will sense the awakening of life within him and won't want to jeopardize that life. Second, feelings that can be associated with childhood experiences can change over time and make way for new feelings. The anger directed at parents remains unchanged as long as we cannot feel it, because we fear this anger, feel guilty about it, and are afraid of the parent's revenge. Once this fear has been experienced . . . and its ramifications have been understood, we are no longer compelled to feel guilty .... This liberation reduces the anger.

$I d$.

46 Id. at 7 ("By 'potential helpers' I mean all those who do not shrink from unequivocally taking the side of the child and protecting him from power abuse on the part of adults.”). 
proxies for her fear of blaming Carl and Mary. ${ }^{47}$ In the end, Rain and Weiss cannot empower Precious, ${ }^{48}$ unless she knows her childhood history and can fault her parents. ${ }^{49}$

\section{B. Precious: Innocent Child, or "Nasty Ass Tramp"}

\section{"Slut! Nasty ass tramp! What you been doin'! Who! Who?"50}

From the moment that Carl actually raped his daughter and that Mary abused her, Precious was clearly an innocent, helpless, and defenseless infant. Nevertheless, they emotionally demeaned her. ${ }^{51}$ They physically assaulted her. They psychologically dominated her. They destroyed her innocence by forcing her to please their base, carnal needs. Throughout Precious, neither Carl nor Mary ever

47 Cf. Arthur Janov, Why We Get Sick and How You Get Well: The Healing Power of Feelings 20 (1997) [hereinafter Janov, Why We GeT SICK]. Survival and continuity do not end the neurotic suffering. His needs:

$[C]$ ontinue through life, exerting a persistent, unconscious force toward the satisfaction of those needs. But because the needs have been suppressed in the consciousness, the individual must pursue substitute gratification. Because he was not allowed to express himself as an infant, he may be compelled to try to get others to listen and understand later in life.

Id.

48 See generally Charles R. Lawrence, III, The Word and the River: Pedagogy as Scholarship as Struggle, 65 S. CAL. L. REV. 2231 (1992) (arguing in part that we can empower ourselves by identifying with the struggles of minorities like blacks who were historically oppressed by external, independent forces under the control of whites). But see Reginald Leamon Robinson, The Word and the Problem of Human Unconsciousness: An Analysis of Charles R. Lawrence's Meditation on Racism, Oppression, and Empowerment, 40 CONNTEMPLATIONS 1 (2008) (arguing that the Word cannot empower individuals because racism, sexism, and oppression are co-created experiences that depend at the very least on the human unconsciousness of blacks and whites, too).

49 See Miller, Banished KnOwledge, supra note 10, at 23 ("For the fear of blaming our parents reinforces the status quo: The ignorance and the transference of child-inimical attitudes persist.").

50 SAPPHIRE, supra note 1 , at 9.

${ }^{51} \mathrm{Id}$. at 14 ("My muver jump in and say, 'Press LISTEN stupid!' I wanna say I ain’ stupid but I know I am so I don’t say nothing.”). 
expressed any shame or guilt about what they had done to their daughter. ${ }^{52}$

By the time she shouted "Slut! Nasty ass tramp!" Mary had more than likely broken Precious' will. Precious thus had learned to rationalize and accept her mother's violence.53 Apart from muttering "I hate her," she just tolerated this maltreatment. ${ }^{54}$ By not recalling what Carl and Mary had done to her body, Precious would virtually tolerate any form of maltreatment from her parents, ${ }^{55}$ perhaps in the worst case believing that her parents' cruelty was love. 56

"Slut! Nasty ass tramp!" symbolically means more than disrespect. Coming from Mary, these words revealed how Precious was required to see herself and others in her world. ${ }^{57}$ In a prior

52 See Miller, BANished KNOWLEDGE, supra note 10 , at 8 ("By the time of my therapy I had grasped . . . that I had been abused as a child because my parents had undergone similar experiences in their childhoods . . . . Because they-like the analysts in my training-were not allowed to feel and thus understand what had happened to them in the past, they were unable to recognize the abuse and passed it on to me without a trace of guilty feelings.").

$53 \mathrm{Id}$. at 21 (arguing that through repression and rationalizations, children fear blaming their parents for the suffering that parents impose on them). See SAPPHIRE, supra note 1, at 76 (even where Precious has a desire to fight back, saying: "I had told myself if she ever come at me like that again I will stab her to def. But when it happen, when she git up off that couch ' $n$ charge toward me like fifty niggers, I ran.’).

54 See, e.g., SAPPHIRE, supra note 1, at 14 ("I'm still grabbing the knife. I hate my muver sometimes. She is ugly I think sometime."); id. at 25 ("where I gonna go to work, how I'm gonna get out HER house? I hate her.').

55 See Miller, For Your Own GOOD, supra note 17, at 4 ("[Children] have no previous history standing in their way, and their tolerance for their parents knows no bounds. The love a child has for his or her parents ensures that their conscious or unconscious acts of mental cruelty will go undetected.”). Miller goes on to write:

[t] he conviction that parents are always right and that every act of cruelty, whether conscious or unconscious, is an expression of their love is so deeply rooted in human beings because it is based on the process of internalization that takes place during the first months of life-in other words, during the period preceding separation from the primary care giver.

Id. at 5 .

56 See Miller, BANished KNOWLEdGE, supra note 10, at 33 ("Love and cruelty are mutually exclusive.").

57 See id. at 46 ("In their behavior these children reflect in every detail the brutality they experienced at home and reveal unmistakably where they learned their destructive behavior."). 
generation, Mary too had suffered obedience training. By "obedience training," Miller means that parents intend to cure a child of in-born impulses to be willful, definitive, lie, cry, rage, or other emotional outbursts. ${ }^{58}$ Mary would do to Precious what was done to her: enforce order and authority. To do so effectively, Mary would begin such training in Precious' infancy. ${ }^{59}$ By permitting Carl to rape Precious, Mary unconsciously sought to dominant her. Although obedience training does not perforce include incestuous rape, Mary's actions conflated them. Moreover, by viewing her as impure, Mary saw Precious as a sexual competitor, thus permitting Mary to attack her daughter as she would any home wrecker. ${ }^{60}$ "Thank you Miz Claireece Precious Jones for fucking my husband you nasty little slut!' 61 Mary's words excused Carl's assaultive act, denied her role in Carl's first rape, and unloaded onto Precious her " 'impure' sexuality by ascribing it to the child through projection." "62 Thus Mary's words rejected Precious' innocence, making her responsible for her own maltreatment.

By spewing "Slut! Nasty ass tramp!" at her daughter, Mary also impliedly suggested that Precious had been the sexual instigator-a precocious child whose silence of her pregnancy

58 See Diane Connors, Alice Miller: For Your Own Good-An Interview, OMni Publications International (1987), available at http://www.no spank.net/miller4.htm (last visited July 15, 2012) ("My antipedagogical position is not directed against a specific type of pedagogy," Miller notes, "but against pedagogical ideology in general, which can be found also in the permissive theories." She fears that as a consequence of adults' arrogant attitudes—including "permissive" attitudes—toward children's feelings, children are trained to be accommodating. But their own voices will be silenced, and their awareness killed. And more blind and arrogant adults will be the result.). See also Philip Greven, Spare the Child: The Religious RoOts of Punishment AND the PSYCHOLOGICAL IMPACT OF PHYSICAL ABUSE 21 (1991) ("Her system of discipline, was begun at a very early age, and it was her rule, to resist the first, as well as every subsequent exhibition of temper or disobedience in the child, however young, until its will was brought into submission to the will of its parents: wisely reflecting, that until a child will obey his parents, he can never be brought to obey God.”).

59 See generally Miller, FOR YOUR OWN GOOD, supra note 17, at 391.

${ }^{60}$ See SAPPHIRE, supra note 1, at 20 ("Fat cunt bucket slut! Nigger pig bitch! He done quit me! He done left me 'cause of you.").

${ }^{61} \mathrm{Id}$.

${ }^{62}$ Miller, Banished KNOwledge, supra note 10, at 43. 
confessed her impurity. ${ }^{63}$ However, Precious' ignorance and innocence were real. Although she knew about sex and sperm, ${ }^{64}$ Precious still did not know how a fetus grew within her. ${ }^{65}$ In Mary's eyes, however, Precious became a wicked child, one who sexually seduced her own father. ${ }^{66}$ Perhaps, having repressed her anger, and having revisited her own recriminations, Mary projected guilt, or at least complicity, onto Precious: "she some kinda freak baby then." 67 Thus, Mary had a socialized "other," her evil daughter, who she could appropriately fight, hate, and fault.

After hurling the invective "slut" at her daughter, Mary could rationalize that Precious, an evil child, lied against good,

63 See Jeffrey Moussaieff Masson, The Assault on Truth: FREUD'S SUPPRESSION OF THE SEDUCTION THEORY 130-31 (Ballantine Books ed., 2003) (1984). On this point, Freud writes:

$[\mathrm{O}]$ ne was readily inclined to accept as true and aetiologically significant the statements made by patients in which they ascribed their symptoms to passive sexual experiences in the first years of their childhood-to put it bluntly, to seduction. When this aetiology broke down under the weight of its own improbability and contradiction in definitely ascertainable circumstances, the result at first was helpless bewilderment. Analysis had led back to these infantile sexual traumas by the right path, and yet they were not true. . . This reflection was soon followed by the discovery that these fantasies were intended to cover up the autoerotic activity of the first years of childhood, to embellish it and raise it to a higher plane.

Sigmund Freud, On the History of the Psychoanalytic Movement (1914), reprinted in THE STANDARD EDition OF THE COMPLETE Psychological WORKS OF SigmUND FreUd, VOL. XIV, at 17-18 (James Strachey ed., 1971) [hereinafter Freud, THE STANDARD EDITION]. But according to Masson, Freud misread Karl Abraham's point, in which he argued that "certain children are seductive, desire the seduction, provoke it, and, the tone suggests, deserve it." MASSON, supra note 63, at 131 .

${ }^{64}$ SAPPHIRE, supra note 1, at 22 ("She felt her mother's hand between her thighs. She stirred, felt her mother's strong fingers and thumb gather into a pinch. She stopped moving and fell back further into the couch as if she was asleep. She didn't have to open her eyes, she knew by the smell in the room her mother's hand was between her own legs .... Her mother's hand inched up Precious' thighs into the wet opening of her vagina. Precious fell for real now into the sleep she had been faking.").

${ }^{65}$ Id. at 12 ("I didn't know how long it take, what's happening inside, nothing, I didn't know nothing.").

${ }^{66}$ See Miller, Banished KNOWLedge, supra note 10, at 40-42 (discussing the mistaken view that children were wicked and thus implicitly responsible for the sexual abuse they suffer.)

${ }^{67}$ SAPPHIRE, supra note 1, at 136. 
loving parents. Mary needed to see herself as good mother who was demonized by her lying child. ${ }^{68}$ She also needed Ms. Weiss, another adult, to join her delusion. And so Mary later told Ms. Weiss, "My little Scorpio chile! Scorpio's crafty. I ain' saying they lie, jus' you cain't always trust 'em."69 And although an older Precious knew that Mary was her tormentor, ${ }^{70}$ Mary's invective and her characterizing Precious as a liar revealed yet another disfiguring implication of obedience training: first, internalize your parent's point of view-you're lying; second, repress your true feelings; and third, reject your actual traumatic memories. In short, Mary told Precious how to understand her pain. Yet, Mary's hypocrisy underscored her own repressed trauma. Mary likely had learned not to fault her caregivers but to blame herself. For example, as he began to fondle his daughter, Carl's simple but strong words muted Mary's anemic protest: "shut your big ass up! This is good for her." 71 By linking parental rape to good, Carl unconsciously revealed a contradiction that was more than likely used by a parental figure or caregiver to rationalize why she traumatized him when he (and Mary) was a child. ${ }^{72}$ Like Carl, Mary then dissociated, which separates feelings from traumatic pain. And having repressed her authentic feelings again, Mary could not feel Precious' pain, and so

${ }^{68}$ Id. at 133-34. Mary said:

I'm a good mother. She had everything. I done tole her that. Pink 'n white baby carriage, little pink bootie socks, dresses; everything I put on her pink. Precious, she, so smiling and healthy. A day don't go by I don't take her out wheeling in the air. Even when it's cold I take her out, to church, to somewhere, me 'n Carl—my husband, I call him-loves Precious. I loves him.

Id.

${ }^{69} I d$. at 134.

70 Id. at 137.

${ }^{71} \mathrm{Id}$.

72 See Miller, Banished KNowledge, supra note 10, at 33 (Parents "would not stop [traumatizing their children] if they were told, as were their own parents thirty years earlier, that one slap more or less does no harm, provided they love the child. Although this phrase contains a contradiction, it can continue to be handed down because we are used to it. Love and cruelty are mutually exclusive. No one ever slaps a child out of love but rather because in similar situations, when one was defenseless, one was slapped and then compelled to interpret it as a sign of love. This inner confusion prevailed for thirty or forty years and is passed on to one's own child."). 
she cannot protect Precious. ${ }^{73}$ Rather, Mary easily became distracted by Carl's penis, which "almost can go in Precious!" "74 With only feelings for herself, Mary wanted Carl to stop, not to protect her innocent child, but rather so that her child would not displace her: "He her daddy, but he was my man!" Still hoping that Ms. Weiss would enable her repressed feelings, Mary declared: "So you can't blame all that shit happen to Precious on me."75

In effect, Mary's “Nasty ass tramp!" impliedly argues: do not blame me. Who then should Ms. Weiss blame? Given Mary's more than likely traumatic childhood, she had learned to fear faulting her parents. And those children like Precious who do must be liars. Moreover, by implication, Mary cannot access her repressed memories, and she had hoped that obedience training would shut Precious' mouth. Yet, if Mary could convince Ms. Weiss that Precious was precocious and lied, and if Ms. Weiss had agreed with her, Precious could have set herself back, a violation to her psychological integrity. ${ }^{76}$ At the very least, Mary would escape judgment, and Precious would suffer what disobedient black children deserve when they defy, lie, disrespect, and dishonor their good, devoted parents. ${ }^{77}$

73 See id. at 30 ("If a mother could feel how she is injuring her child, she would be able to discover how she was once injured herself and so could rid herself of her compulsion to repeat the past.").

${ }^{74}$ SAPPHIRE, supra note 1 , at 134.

75 Id. at 136.

76 See MASSON, supra note 63, at 133. He writes:

To tell someone who has suffered the effects of a childhood filled with sexual violence that it does not matter whether his memories are anchored in reality or not is to do further violence to that person and is bound to have a pernicious effect. A real memory demands some form of validation from the outside world - denial of those memories by others can lead to a break with reality, and a psychosis. The lack of interest in a person's store of personal memories does violence to the integrity of that person.

Id.

77 Cf. Miller, Banished Knowledge, supra note 10, at 30 ("For thousands of years, all religious institutions have exhorted the faithful to respect their parents ... . But when a person has no reason to respect his parents, he must, it seems, be coerced into doing so. The dangerous effect of such coercion is that any criticism of parents is called a sin and results in strong feelings of guilt. Because religions teach that parents, even if already dead, must be shielded under any circumstances, they do so at the cost of the parents' children.”). 
Regardless, since her infant rape, Precious carried repressed trauma in her body. She harbored latent hatred for Carl. She expressed quietly her clear anger and hatred of Mary. Because Mary never told her the truth, Precious would remain confused, and she could only access what she had repressed through a dream, which symbolically revealed but actually hid experiences that she had suffered in infancy, lest the recalled pain might kill her. ${ }^{78}$ In one such dream, Precious relived one of her infant assaults, in which Mary forced her to perform oral sex. "I am choking between her legs .... She is smelling big woman smell. She say suck it, lick me Precious." 79 During this dream, Mary sweet talked her just as Carl did when he would rape her. Raped, choking, and suffocating, Precious-just like Carl and Mary-dissociated or split off, thus uncoupling her pain from her repeated rapes. Splitting off is repression. ${ }^{80}$ And for a time, despite its consequences, repression saved Precious.

In the end, Mary's words, "Slut! Nasty ass tramp!" attempted to rewrite her brutally exploitative history with Precious. ${ }^{81}$ Precious must be at fault. Although Mary described Carl as "a high natured man," 82 Precious caused Carl to rape her. And by taking her man, Precious breached her mother's trust. Put simply, Mary was betrayed by another capable, sexually available (infant) woman-her own daughter no less—in her house. Ironically, Mary and Precious perhaps played similar, exploited roles in their childhoods. Yet, to prevent herself from recalling her sexual

78 ARthur Janov, The NeW Primal SCREAM: Primal Therapy 20 YEARS ON 75 (1991) ("It is crucial to understand that nightmares are forms of defense. Against what? DEATH. Quite literally. For the person in a nightmare is the same as the person on the verge of reliving his birth or other early life and death trauma; his vital signs are lethal in an attempt at fleeing and repressing the pain .... Therefore, dreams are defenses against nightmares, and nightmares are defenses against death.”).

79 SAPPHIRE, supra note 1, at 60 ("That night I dream I am not in me but am awake listening to myself choking, going a huh a huh A HUH A HUH A HUH.”).

80 See JANOv, Why We GeT SiCK, supra note 47, at 22 (explaining that while the maltreated child consciously shifts away from her authentic feelings and being so that she can please the parent, she acts increasingly "unreal, that is, not in accord with the reality of [her] own needs and desires. In a short time the neurotic behavior becomes automatic").

${ }^{81}$ SAPPHIRE, supra note 1, at 36 ("After my baby and me come out of the hospital my muver take us down to welfare; say I is mother but just a chile and she taking care of bofe us'es. So really all she did was add my baby to her budget.").

${ }^{82} \mathrm{Id}$. at 134. 
maltreatment and to identify with, and to properly respect, her abusive parents, Mary was arguably forced to treat Precious sternly because she needed obedience training.

Yet, throughout Precious, Mary clearly used her daughter as a proxy for love, care, warmth, compassion, and sexual satisfaction. She could have acquired these affections from an adult male partner, if she had not repressed the trauma of her childhood and could actually express her latent hatred for her own sexual exploiters. In this way, Precious is an unfortunate tale of victims who became tormentors of their own daughter.

\title{
II. THREE EXPLANATORY TALES FOR CHILDHOOD MALTREATMENT
}

\section{A. Critical Race Theory: Race Consciousness and the Violent Destruction of the Black Family}

\author{
"Crackers is the cause of everything bad. \\ It why my father ack like he do. \\ .... So be fuck me, fuck me, beat me, have a chile by me." 83
}

Within CRT, Race Crits adopt a race-consciousness framework, so that they can understand how white supremacy, law, and the "subordination of people of color have been created and maintained." 84 And as part of its antisubordination praxis, Race Crits wish to alter the "vexing bond between law and racial power." 85 Thus, they would perforce explain Precious' maltreatment by looking to slavery and the black family's breakdown. They would not blame black mothers by default. ${ }^{86}$ Accordingly, present effects of past discrimination deny ordinary

\section{Id. at 36.}

84 Kimberlé Crenshaw, Introduction, in CRITICAL RACE THEORY: THE KeY Writings That Formed THE MOVEMENT, at xiii (Kimberlé Crenshaw et al. eds., 1995).

$85 \mathrm{Id}$.

86 See, e.g., Wing \& Wesselman, supra note 11, at 273 ("From slavery on, Black women have fallen outside of the class labeled 'ideal mothers' . . Moreover, slave mothers were considered bad mothers and blamed for the devastating effects of slavery on their children."). See also DOROTHY ROBERTS, KILLING THE BLACK BODY: RACE, REPRODUCTION, AND THE MEANING OF LIBERTY (1997). 
people, ${ }^{87}$ especially blacks, Latinos, and women, formal and substantive equality. ${ }^{88}$ Although scholars have rejected a purely structuralist approach, ${ }^{89}$ Race Crits advance this premise, ${ }^{90}$ principally because they wish to hold America liable for laws that derive from slavery and that impact people of color today. Yet, this structuralist premise deftly poses blacks as victims and fashions whites as singularly powerful reality co-creators, who marginalize blacks, even if they do so unconsciously. ${ }^{91}$ Broadly speaking, to be empowered, blacks must critique not just their self-annihilating, self-

87 See Robinson, Human Agency, supra note 16, at 1363 n.9 (defining "ordinary people" as all "non-elite Asians, blacks, American Indians, Latinos, whites, and women, including immigrants").

88 See, e.g., Melvin L. Oliver \& Thomas M. Shapiro, Black Wealth, White Wealth: A NeW Perspective on Racial Inequality (1995) (discussing racial inequality through an analysis of private wealth).

89 See, e.g., Robinson, Human Agency, supra note 16; Reginald Leamon Robinson, The Way of Sacred Tibetan CRT Kung Fu: Can Race Crits Teach the Shadow's Mystical Insight and Help Law Students "Know" White Structural Oppression in the Heart of the First-Year Curriculum? A Critical Rejoinder to Dorothy Brown, 10 MiCH. J. RACE \& L. 355 (2005) [hereinafter Robinson, The Way of Sacred Tibetan CRT Kung Fu]; JAMES MCWhORTER, LOSING THE RACE: SELF-SABOtAGE IN BLACK AMERICA (2001) (arguing that black Americans prevent themselves for attaining what appears to be elusive goals by adopting a mindset in which not their choices but America's racist history burdens them); JAMES T. Patterson, Freedom Is Not EnOUgh: The Moynihan Report and AMERICA'S StRUGgLE OVER BLACK FAMILY LIFE FROM LBJ TO OBAMA 147 (2010) (citing Glen Loury, A New American Dilemma, The NeW Republic, Dec. 1984, at 14, in which the Harvard economist wrote: "The bottom stratum of the black community has compelling problems which can no longer be blamed solely on white racism and which force us to confront fundamental failures in black society.").

90 See, e.g., Crenshaw, Race, Reform, and Retrenchment, supra note 15, at 1331-87.

91 See generally Robinson, Human Agency, supra note 16 (examining how Critical Race Theory relies on a framework for analyzing African-American slaves and blacks as not having sufficient human agency against white structural oppression); Robinson, The Way of Sacred Tibetan CRT Kung Fu, supra note 89 (providing a critique against Brown's Critical Race Theory textbook because it does not adequately demonstrate how law students can use human agency to "know" white structural oppression in the first year curriculum); see also Reginald Leamon Robinson, Poverty, the Underclass, and the Role of Race Consciousness: A New Age Critique of Black Wealth/White Wealth and American Apartheid, 34 IND. L. REV. 1377, 1438-43 (2001) (book review) (expressly arguing against the idea that blacks lack co-creative power for the personal experiences and social realities in which they participate and/or observe). 
deceptive, and life devaluing practices ${ }^{92}$ but also the core beliefs of the socialized other, viz., whites. ${ }^{93}$

For Race Crits, slavery and Jim Crow show us how whites impacted blacks, especially because they required blacks to brutalize their children, who needed to learn plantation etiquette. ${ }^{94}$ Under this strict obedience norm, children had to abide adults and elders, who strictly enforced compliance by violence ${ }^{95}$ or humiliation. ${ }^{96}$

92 See, e.g., Renee Bowman, Children's Remains Found in Home Freezer, GRANDPARENTS BLOG-Dedicated TO Austin AND IsABELLA, http://un happygrammy-grandparentsblog.blogspot.com/2010/03/adopters-who-abusekill.html (last visited July 15, 2012) (adopting mother murdered two of her three adopted daughters, and she was later arrested, charged, convicted, and sentenced to life in prison after her daughter escaped and was found wandering the streets with lesions on her buttock, open sores, bruises on her hands and lips; In Re Sean E., 0610977 (Md. 2010) (A mother forced her child to shoplift, beat him daily in the car after picking him up from school, threatened to kill him because he ate too slowly, and awoke one night every half hour to place hot pepper seeds in his eyes and to assault him with one or two belts, using either the rounded tip or the bucket end). (This case is a sealed juvenile file.)

${ }^{3}$ Cf. Peter Wallsten, For an Arizona Sheriff, Not a Moment of Silence, WASH. POST, Jan. 10, 2011, at C1, C3 (In explaining why Jared Loughner shot and wounded twenty people, including Representative Gabrielle Giffords, and killed a nine-year old girl and a federal judge, Pima County Sheriff Clarence Dupnik faulted structural factors like mass media, saying " 'I'd just like to say that when you look at unbalanced people, how they are-how they respond to the vitriol that comes out of certain mouths, about tearing down government, the anger, the hatred, the bigotry that goes on in this country is getting to be outrageous.' "); Jason Horowitz \& Lisa DeMoraes, After Traedy, Toxic Talk in the Media Cross Hairs, WASH. Post, Jan. 10, 2011, at C1, C3 (In response to the Loughner shootings, Keith Olbermann "blamed Sarah Palin's rhetoric, saying that if she did not 'repudiate her own part, however tangential, in amplifying violence and violent imagery in American politics, she must be dismissed from politics." ").

${ }^{44}$ Marie Jenkins SchwartZ, Born in Bondage: Growing Up ENSLAVED IN THE ANTEBELLUM SOUTH 98 (2000) ("Owners recognized the influence of parents had over [their children] and urged them to subdue children and turn them into dutiful and submissive servants."); $i d$. (white masters required strict obedience to black "mother[s], father[s], other relatives, and caretakers"); $i d$. at 99 (slaves preferred to physically punish their children or switching, rather than allow white masters to impose their will or thwart their parental prerogative, and when "her Alabama master tried to punish Eliza Evans for sassing him, the young girl ran to her grandmother for protection, only to be whipped by the older woman. The master left satisfied that Eliza's insolence had been suitably punished ....”).

${ }^{95} \mathrm{Id}$. at 99 (caregivers used physical violence to force children to participate in "races organized by the overseer at a watermelon feast"). 
Under Jim Crow, blacks conformed to white privilege and power, ${ }^{97}$ by teaching their children to know their place $^{98}$ and to yield to whites. ${ }^{99}$ Blacks taught children to listen "widout no ears en seein widout no eyes."100 From a Race Crit perspective, external, objective forces compelled blacks to use the expediency of harsh, brutal punishment so that they could protect their children from the arbitrary vagaries of slavery and white supremacy. This punishment corrupted child-rearing discipline into a dark, preemptive violent abuse. ${ }^{101}$

In this way, African culture in and of itself cannot explain the harsh physical punishment that blacks inflicted upon their children. Thus, black oppression explains why Carl and Mary maltreated Precious. ${ }^{102}$ According to Race Crits like Kimberlé Williams Crenshaw, racial subjugation distorts the mindset of blacks, causing them to harm their children. Specifically, Crenshaw has

96 C.f. Herbert Gutman, The Black Family in Slavery and FREEDOM 201-20 (1964) (presenting accounts discussing kin relationships that show how parents and elders used respect, emotional control, ridicule, and harsh discipline to teach young children how to survive the travesties of slavery and the trials of Jim Crow).

97 See LeOn Litwack, Trouble in Mind: Black Southerners IN THE AGE OF Jim CROW 1-7 (1998) (illustrated by allusion to anecdotal story).

98 See id. at 4 ("Son ... a catfish is a lot like a nigger. As long as he is in his mudhole he is all right, but when he gits out he is in for a passel of trouble. You 'member dat, and you won't have no trouble wid folks when you grows up.”).

99 Remembering Jim Crow: African Americans Tell About LifE IN THE SEgREgated SOUTH 7 (William H. Chafe et al. eds., 2008).

100 SCHWARTZ, supra note 94, at 99-100.

101 See, e.g., id. at 101 ("When one little girl in Virginia accidentally came upon some adults preparing to eat lamb, a food normally unavailable to slaves, an old man took her 'out back of the quarter house' and whipped her severely, explaining: 'Now what you see, you don't see, and what you hear, you don't hear.' "); $i d$. at 100 ("Adult slaves worried about the tendency of young children to blurt out information to the white folks that would prove detrimental to their interest. Penny Thompson told her master of a plot to help slaves escape from his plantation in Alabama."); LITWACK, supra note 97, at 413 (Exasperated, she remarked: "But do you know, Susie never tells us a thing about her life or her friends, and we couldn't, if we tried, make her tell what goes on in the society she belongs to.").

${ }^{102}$ Cf. William Julius Wilson, More Than Just Race: Being BLACK AND POOR IN INNER CITY 151-52 (2009) (“[A]ll poor women could find meaning and purpose in child rearing despite serious financial hardship, and African American women have, on balance, formed particular views on family through unique circumstances tied to their experiences with racial oppression in America."). 
argued that external, objective forces like racism coerce blacks into creating their worlds. ${ }^{103}$ In this way, racial subjugation becomes hegemonic, which means that the oppressed are complicit in their oppression. ${ }^{104}$ Precious came to realize that external, objective forces explained her suffering, and so she said: "Crackers is the cause of everything bad."105

Unfortunately, African child-rearing practices were coercive and enforced with physical discipline. ${ }^{106}$ According to Andrew Billingsley, "Ashanti fathers (unlike mothers) tend to be overly strict in exacting obedience, deference, and good behavior from their children."107 Since slavery, blacks have prepared their children for the evils they perceived. As in Africa, ${ }^{108}$ children had to respect and

103 Cf. Crenshaw, Race, Reform, and Retrenchment, supra note 15, at 1357 ("Black people do not create their oppressive worlds moment to moment but rather are coerced into living in worlds created and maintained by others. Moreover, the ideological source of this coercion is not liberal legal consciousness, but racism.").

104 Id. at 1351 (citing Robert Gordon, "the most effective kind of domination takes place when both the dominant and dominated classes believe that the existing order, with perhaps some marginal changes, is satisfactory, or at least represents the most that anyone can expect, because thing pretty much have to be the way they are").

105 SAPPHIRE, supra note 1 , at 34.

106 See Meyer Fortes, Kinship and Marriage Among the Ashanti, in AFRICAN SYSTEMS OF KINSHIP AND MARRIAGE 252, 268 (Alfred Reginald Radcliffe-Brown \& Daryll Forde eds., 9th ed. 1967) (The sons' “moral and civic training, in particular, is [the father's] responsibility and this gives him the right to punish them if necessary.”); Delores E. Smith \& Gail Mosby, Jamaican Child-Rearing Practices: The Role of Corporal Punishment, 38 ADOLESCENCE 369, 369-81 (2003). Smith and Mosby write:

The etiology of such harsh disciplinary practices in the Caribbean has been pondered. Although many arguments have been forwarded, the most pervasive and often cited explanations point back to heritage, history, tradition, and socialization. Several authors have expressed the view that the extreme authoritarian style, along with the excessive discipline meted to children, stems from the region's West African heritage combined with learned behavior, specifically from the brutality of slavery. These dynamics are bolstered by the religious sanction of "saving the rod and spoiling the child."

Id. at 373 .

107 ANDREW BillingSLEY, BlaCK FAMILIES IN WHite AMERICA 44 (1968) (citing Fortes, supra note 106, at 252-84.

108 See GUTMAN, supra note 96, at 219-20 (1976); BILLINGSLEY, supra note 107, at 44 (citing Fortes, supra note 106, at 268) ("To insult, abuse, or assault one's father is an irreparable wrong, one which is bound to bring ill luck. While there is no legal obligation on a son or daughter to support a 
defer to adults and elders, which required them to repress their authentic feelings from blacks and nonslaves. ${ }^{109}$ During slavery, blacks practiced "hardening" by bathing infants in cold water or exposing their limbs to the cold, ${ }^{110}$ which perhaps contributed to the high infant mortality. 111 Even if slaves used "hardening" to ensure an infant's plantation survival, 112 infants needed not cold but warmth, love, food, and shelter. ${ }^{113}$ Clearly, "hardening" traumatized an infant's body. An infant had to learn to repress their authentic feelings, especially anger and fear at not having her immediate needs met. As a toddler, youth, or young adult, that infant would exhibit neurotic tendencies, ${ }^{114}$ including rigid compliance ${ }^{115}$ and a close bond with her tormentors. ${ }^{116}$ However diluted, altered, or corrupted by time and context, blacks still embrace obedience

father in his old age, it would be regarded as a shame and an evil if he or she did not do so.").

109 GUTMAN, supra note 96, at 219.

110 See SCAHWARTZ, supra note 94, at 43 ("Slaves followed their own customs in caring for newborns .... Dr. Dewees recommended against deliberate 'hardening' of children by bathing them in cold water or exposing their limbs to cold.").

${ }^{111}$ Id. ("For [Dr. Dewees], the high mortality rate among poor children, whose parents routinely exposed them to the elements, offered proof that such a strategy did not work to promote health."). See generally WILMA A. DUNAWAY, THE AFRICAN-AMERICAN FAMILY IN SLAVERY AND EMANCIPATION 114-49 (2003) (discussing the structural interferences with breastfeeding and other child-rearing needs by slave parents such as the need for productivity as contributing to higher slave infant mortality rates).

112 SCHWARTZ, supra note 94, at 43 ("Slave mothers, of course, had a special incentive to 'harden' their children. They knew they must prepare their children to survive the years of hardship and deprivation that awaited them.").

113 See generally Alice Miller, BANished KnOwLedge, supra note 10 (discussing a child's basic emotional needs and the impact of the child when they are traumatized instead of having their caregivers meet those needs).

114 See JANOV, Why WE GET SICK, supra note 47, at 21 (arguing that if a child begins to suppress his first feelings, the neurotic process begins, and then by the by, the child develops dual selves: one real, the other unreal, and " $[t]$ he unreal self is the cover of those feelings and becomes the façade required by neurotic parents in order to fulfill needs of their own").

115 See GuTMAN, supra note 96, at 217-20 (elders were treated with respect and had children and adults undergo a strict discipline).

116 See generally Sigmund Freud, The Aetiology of Hysteria, in THE Freud Reader 96 (Peter Gay ed., 1989) [hereinafter Freud, The Aetiology of Hysteria] (children who suffer trauma forge a life-long bond to their exploitative and abusive parents). 
training and elder respect, an African child-rearing practice, which in part explains why Carl and Mary maltreated Precious. ${ }^{117}$

In this way, Precious is a novel about obedience, about cruelty as love, about deferring to elders, about knowing your place, and about not trusting non-slaves. 118 To be sure, this "old school" parenting was a keystone for black survival. Children, innocent and naive, had to learn to distrust non-slaves. Unfortunately, despite the Race Crit perspective that explains black self-annihilation as a function of white racism, blacks like Carl and Mary continue to embrace obedience training, not because they need it today, but because they suffer from emotional blindness and a fealty to violent parenting, principally to rationalize how they were abused. After all, we know that abused parents will maltreat their children. In short, "cruelty as love"119 was, and still is, an integral part of black childrearing practices.

117 See Abram Kardiner \& LiOnel Ovesey, The Mark of OpPRESSION: EXPLORATIONS IN THE PERSONALITY OF THE AMERICAN NEGRO 7 (1951) ("These unconscious processes occur in representational forms that are disguised either through symbolization, condensation, or several other processes which render them incapable of overt recognition. The grand purpose of this complex maneuver is to prevent these motivations from becoming known, because their acknowledged presence would expose the subject to some danger."). See also Rollo May, The Discovery OF BeING: WRITINGS IN EXISTENTIAL PSYCHOLOGY 26-27 (1983). Arguing against the idea that neurosis means that a person has failed to adjust, May writes:

An adjustment is exactly what neurosis is; and that is just its trouble. It is a necessary adjustment by which centeredness can be preserved; a way of accepting nonbeing in order that some little being may be preserved. And in most cases it is a boon when this adjustment breaks down.

Id. (emphasis in original).

118 See GUTMAN, supra note 96, at 219-20 ("Socializing children to respect all elderly blacks also may have taught then to hide slave feelings and beliefs from nonslaves. Asked about the attitudes of children toward their parents, Laura Towne said, 'I never saw it equaled anywhere-their love and obedience.' That was so even though parents 'were exceedingly severe.' She remembered only one instance of 'anything like indulgence toward children.' 'I think they . . . will bear pain to any extent,' said Towne. 'If a boy cries too early because he is suffering they will deride him. He must be stoical under trouble and his parents will not suffer complainings. Children undergo a regular discipline." ").

119 Miller, BANished KNOWLedge, supra note 10, at 31. 


\section{B. Marxism: Alienation Theory and the Violence in the Black Family}

Like CRT, Marx's alienation theory ${ }^{120}$ cannot completely explain why Carl and Mary maltreated Precious. Under this theory, Marxists first and foremost would appeal to the larger, external forces of capitalism, and they would argue that these objectifying forces have come to increasingly dominate the lives of the poor, women, workers, etc. ${ }^{121}$ These forces instill workers with poorer inner lives. Through the political economy of capitalism, workers became beset by alienated and alienating experiences. ${ }^{122}$ In short, workers become "nature's bondsman."123

By nature's bondsman, Marx meant that workers became slaves, who have very little control over their external worlds, having been tied to machines and "turn[ed] into machines."124 They would suffer privations, live in hovels, bear deformities, live like brutes, and become mental midgets. ${ }^{125}$ In effect through the workers' own hands, capitalism's external forces made "for the worker idiocy, cretinism."126 In this way, through the ever-increasing domination of the captains of capitalism, the worker alienated himself from himself. ${ }^{127}$

Alienation can lead to self-annihilating acts (e.g., drug addiction or alcoholism). However, it does not follow that parents, for example, must injure their children. Although Marx makes it clear that capitalism as an external force hides the alienation that

${ }_{120}$ Karl Marx, Economic and Pbilosophic Manuscripts of 1844, in THE MARX-Engels ReAder 66, 71-72 (Robert C. Tucker ed., 2d ed. 1978) [hereinafter Marx, Economic and Philosopbic Manuscripts] (" $[\mathrm{T}]$ his realization of labour appears as loss of reality for the workers; objectification as loss of the object and object-bondage; appropriation as estrangement, as alienation.") (emphasis in original).

121 See Judy Cox, An Introduction to Marx's Theory of Alienation, 79 INT'L SOCIALISM 41 (1998).

122 Marx, Economic and Philosophic Manuscripts, supra note 120, at 72-73.

${ }^{123} \mathrm{Id}$. at 73 . "[T] he more values he creates, the more valueless, the more unworthy he becomes; the better formed his product, the more deformed becomes the worker; the more civilized his object, the more barbarous becomes the worker; the mightier labour becomes, the more powerless becomes the worker; the more ingenious labour becomes, the duller becomes the worker and the more he becomes nature's bondsman." Id.

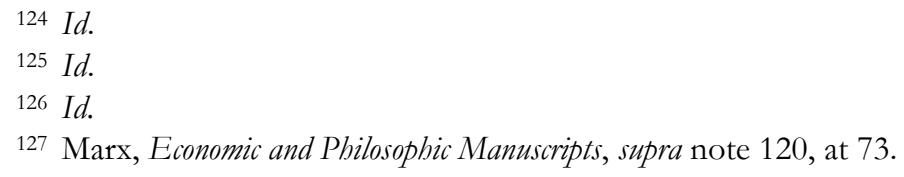


comes from wage worker production, and although he points out that human hands produce alienation, ${ }^{128}$ workers unfortunately might not immediately understand why they have become more like animals who simply eat, drink, and procreate. ${ }^{129}$ By becoming more bestial than human, by having external objects exercising power over the worker, and by not having structural or institutional ways to "treat himself as the actual, living species,"130 Marx might argue that workers become disheartened by their alienating enslavement to machines. He might argue that workers, once disheartened by other external forces of capitalist production, become aggressive and socio-pathic because they have lost any real connection to their work as a "life-activity, productive life itself."131 Hence without a "species being," or a way to feed their spiritual life through practices that are in fact "part of human life and human activity,"132 i.e., through meaningful work, workers can become mere brutes, capable of hurting and violating others, including themselves.

In this sense, objective, external or structural forces, some of which were racism and white structural oppression, can arguably explain why in Precious, Mary severely maltreated her daughter. At this juncture, CRT's historicity of racism and Marx's alienation theory conflate. American slavery clearly involved socio-political and economic forces arrayed against Africans, all designed to dominate their minds, direct their labor, and control their bodies. Like European workers, slaves were denied a right to experience their "species being" through meaningful work. ${ }^{133}$ Hence upon entering the Americas and into forced labor, slaves suffered the very

128 Loyd D. Easton, Alienation and History in the Early Marx, 22 PHIL. \& Phenological Res. 193, 195 (1961) (adopting G.W.F. Hegel's view of alienation from Phenomenology of Mind, Marx argues that "wealth is "the created result of the labor and action of all' ').

129 Marx, Economic and Philosophic Manuscripts, supra note 120, at 74 ("As a result, therefore, man (the worker) no longer feels himself to be freely active in any but his animal functions-eating, drinking, procreating, or at most in his dwelling and in dressing-up, etc.; and in his human functions he no longer feels himself to be anything but an animal.").

130 Id. at 75.

131 Id.

$132 \mathrm{Id}$.

133 See, e.g., Christine Barrow, Contesting the Rhetoric of Black Family Breakdown' from Barbados, 32 J. COMP. FAM. STUD. 419, 419-20 (2001) ("Slave men and women alike were defined and reconstructed as units of labour to fulfill the economic demands of what was perhaps the most dehumanising of capitalist systems ever to have existed.’'). 
alienation about which Marx wrote so poignantly. ${ }^{134}$ But critically important, as in the case of workers, if slavery robbed blacks of their "species being," not all blacks as a result sexually violated their children. After all, Sigmund Freud became aware that many of his clients were suffering from neuroses that were caused by sexually abusive parents, perhaps fathers, ${ }^{135}$ in well-to-do bourgeois families. ${ }^{136}$ We cannot simply attribute child maltreatment to the stress of economic privation and the mind-numbing experiences of alienation. 137 Yet, if Marx attributed the death of workers' inner life to economic exploitation and their lost connection to nature, and if alienation affects the possessing classes too, it must follow that structural alienation does not in and of itself contribute to the

134 See generally Marx, Economic and Pbilosophic Manuscripts, supra note 120 , at 66-125.

135 Miller, BANisHed KNOWLEDGE, supra note 10, at 55. In a letter to Wilhelm Fliess, Freud wrote: "Unfortunately, my own father was one of these perverts and is responsible for the hysteria of my brother (all of whose symptoms are identifications) and those of several younger sisters. The frequency of this circumstance often makes me wonder." Id. Miller also wrote:

Fliess's son, Robert Fliess, however, later became a psychiatrist and analyst and published three books containing some very revealing material on sexual abuse by parents of their own children. It took Robert Fliess many decades to find out that, at the age of two, he had been sexually abused by his father and that this incident coincided with Freud's renunciation of the truth .... [Robert] was convinced that his father had deterred Freud from further developing the trauma theory. That theory would have inevitably caused Wilhelm Fliess guilt feelings, so his son believes.

Id. at 55-56.

136 See generally FREUD, The Aetiology of Hysteria, supra note 116, at 96111 (Peter Gay ed., 1989) (brilliantly linking hysteria or trauma with the power of parents to punish and to foist their sexual desires onto children, who were at the same time weak, dependent, and sexually aroused, all of which led to repression, symptoms, symbolisms, and the idealization and life-long bonding of damaged children to exploiting and abusive parents).

137 See, e.g., Barrow, supra note 133, at 426-27 ("The peak in 1990/1

in physical abuse and neglect and the high level in the subsequent year are officially attributed to the stresses of economic recession, specifically to the period of stabilisation and structural adjustment in Barbados when parents were unable to meet basic needs and responded either by taking out their frustrations on their children or not giving them the necessary care and attention. The increase since 1994, however, is cause for concern though it is not yet clear whether this reflects an upward trend in cases of child abuse.") (internal citation omitted). 
horrific maltreatment experiences of Precious and of real-world children. The etiology of Precious' incestuous rape must lie elsewhere.

Unfortunately, masters rejected their slaves' humanity by denying them what Abram Kardiner and Lionel Ovesey called incomplete "reciprocity of feelings." 138 By so doing, they destroyed any natural human emotional interchange between institutionally powerful whites and weaker blacks. Without such an exchange, masters could reduce blacks to things, thus treating them little differently from animals. Furthermore, no true emotional exchange could take place between master and slave, for if the slave dared to express his rage, anger, or indignation that affronted the white master's presumed position of authority, then the master's resort was actual or symbolic violence, i.e., selling him, whipping him, or killing him. ${ }^{139}$ Moreover, slaves had no respite from their alienated conditions within their family, principally because their marriages and paternity were without legal force on the plantation. ${ }^{140}$ Even when masters interfered with the slave family, or forced a pregnant slave to work, slaves were without any real power to ward off the master or garner special treatment for a slave with child. In short, due to the powerful forces arrayed against them, slaves could not demand that whites treat them as humans who had "species being."

In Precious, Mary arrayed such power against her daughter. She virtually reduced her daughter to a slave. After attending "Each One Teach One," Precious became aware of her alienating exploitation. She had been used for beating, cooking, cleaning, and raping; however, neither Carl nor Mary recognized her inner being. ${ }^{141}$ Her parents never loved her as a child, as a daughter, with her own needs.

138 KARDINER \& OVESEY, supra note 117, at 43.

${ }^{139} I d$. ("The rage or protest of the slave could be ignored or treated with violence.").

140 Id. at 44.

141 SAPPHIRE, supra note 1, at 64. Precious states:

I go home. I'm so lonely there. I never notice before. I'm so busy getting beat, cooking, cleaning, pussy and asshole either hurting or popping . . . . I never feel the loneliness. It such a small thing compare to your daddy climb on you, your muver kick you, slave you, feel you up. But now since I been going to school I feel lonely. Now since I sit in circle I realize all my life, all my life I been outside of circle. Mama give me orders, Daddy porno talk me, school never did learn me. 
Precious is an ironic tale of exploitation, alienation, and the black family. In this tale, rather than captains of industry, Carl and Mary were the exploiters. Precious served them with her body as a sexual object, her mind as a devotee of her mother's needs and wishes, and her labor as a servant who cooked and satisfied her mother's food needs. ${ }^{142}$

Unlike the usual tale of worker exploitation and alienation, Mary symbolized a cruel irony. She owned no capital. She possessed things, but she had become a lumpenproletariat or underclass, a low-life criminal who raped, exploited, and demeaned her daughter, all in the name of greater exploitation with welfare checks. ${ }^{143}$ Mary wanted Precious to live in her apartment and told her to lie about where Mongo lived, so that Mary would have another source of state-based income. Through Precious, Mary controlled what she never possessed in her own life-real power over her labor, things, and life.

It's not so clear that individuals overcome the effects of alienation by dominating others. Regardless, Marx would argue that Mary's nature was determined within the specific material conditions of the world in which she lived.144 Yet, under Marx's alienation theory, society co-created its modern, material conditions through past actions. A future world in which material privations were imposed on the bottom segment of society did not have to exist. Rather, "human beings were shaped by the society they lived in, but also ... they could act to change that society."145 In short, we, literally all of us, are not only "world determined" but also "world producing.",146

In Precious, Mary caused her daughter to suffer deep alienation, and in the worst case, she actually intended to break Precious so that she would not have any real sense of her inner power. In Miller's work, such power is called authentic self or feelings. Regardless, this power would have given Precious the

$I d$.

${ }^{142} I d$. at 22 (Her mother was sleep. She'd be back to clean and "fix breakfast for her mother." And then Precious wondered: "Why Mama never do anything? One time I ax her, when I get up from her knocking me down, she say, That's what you here for.").

143 Id. at 19.

144 Cox, supra note 121, at 2 (" $[\mathrm{H}]$ umans [do not] have a fixed nature which exists independent of the society they live in.").

$145 \mathrm{Id}$. at 1.

${ }_{146} \mathrm{Id}$. 
ability to know from the very beginning that her maltreatment experiences were destructive to her well-being and simply wrong. She would have done as some children today have done: call 911 or kill their parents. ${ }^{147}$ Unfortunately, Precious didn't ultimately defend herself. Rather, it was Ms. Rain and Ms. Weiss who helped Precious find a new way to express herself and to acquire functional work skills so that she could survive on her own. However, she never truly gained access to her childhood memories, her history, and thus her empowerment. One example of Precious' lack of inner power is that she still viewed Ms. Weiss with deep suspicion, not realizing that Mary had taught her to view the socialized other-whites-as the enemy. Without this sense of inner power, Precious did not realize that Mary-her mother-was the primarily source of her personal torment.

\section{Alice Miller: Racism, Childhood History, and Poisonous Pedagogy}

"From the very beginning I was physically, psychically, and sexually abused.... Our parents claims to have learned cruelty from the whites and deny their own parents' contribution."148

Before and since slavery, children have been the objects of cruelty, humiliation, and violence. ${ }^{149}$ As such, childhood

147 See generally P. Solomon Banda, Colo. Boy Remains in Custody in Killing of Parents, Associated PREss, Mar. 4, 2011, http://news.yahoo.com/s/ ap/20110304/ap_on_re_us/us_colorado_family_shot (describing story of twelve-year-old boy who shot and killed his parents, Charles and Mary Long, both of whom were active in the local Evangelical Free Church, and two young siblings); Anastasia Toufexis, Hannah Bloch \& Jeanne McDowell, When Kids Kill Abusive Parents, TIME, Nov. 23, 1992, available at http://www.time. com/time/magazine/article/0,9171,977079,00.html (Town folks collected signatures in a petition for "Billie Joe Powell, a 16-year-old girl charged with fatally shooting her father, who had allegedly abused her. . . . Charles Patrick Ewing [psychologist and attorney] of the State University of New York at Buffalo [who explained the unusual sympathy the town had for Billie Joe said]: 'We take the commandment to 'honor thy father and thy mother' very seriously. The implication is that you're supposed to honor your parents even if they abuse you." ").

148 Miller, BANished KNOWLEDGE, supra note 10, at 33.

149 See, e.g., Mason P. Thomas, Jr., Child Abuse and Neglect Part I: Historical Overview, Legal Matrix, and Social Perspectives, 50 N.C. L. REV. 293, 293 (1972) ("The phenomenon of child abuse and maltreatment is deeply rooted in our cultural and religious history. It is as old as civilization itself."). 
maltreatment predates American Negro slavery and Karl Marx, which cannot be explained simply by race-consciousness oppression or by capitalism's alienation. Without overly discounting structural forces, Miller's framework actually explores what CRT and Marx's alienation theory appear to ignore. Indeed, racism's historicity matters, and the collective history of worker exploitation cannot be overlooked. Yet, Precious' childhood history, which would shape her life perhaps forever, was forged in the fire of Carl and Mary's dark repression.

In explaining what happened to Precious, this Essay relies on Miller's psycho-existential framework. ${ }^{150}$ In The Body Never Lies, Miller argues that pedagogical parenting, or moral training, destroys a child's vitality, spontaneity, and true feelings. 151 If caregivers use violence, humiliation, and manipulation during infancy, children will repress memories of such pain and cruelty, leading to self-deception. They will identify with traumatizing parents, leading to emotional blindness. Because their bodies never forget, self-deception can lead to numbness, illness, depression, type II diabetes, hypertension, violence, crime, jail, broke families, cancer, bad grades, and obesity. ${ }^{152}$

Thus, by holding structural forces in abeyance, Precious tells the story of how the victim became a destroyer. 153 Carl and Mary carried out against their daughter what they had more than likely suffered as an innocent, impotent children. By innocent, Miller means that the child "is defenseless and as yet bears no responsibility for others."154 By impotent, she means that a child, perhaps an infant, is literally at the mercy of her caregivers for love, nurturance, and shelter. At the outset, neither Carl nor Mary

${ }^{150}$ Cf. Reginald Leamon Robinson, Trauma, Creativity, and Unconscious Confessions: The Lost Childhood History Bebind L. Frank Baum's The Wonderful Wizard of $\mathrm{Oz}_{z} 20$ S. CAL. INTERDIS. L.J. 145 (2010) (relying on Alice Miller's psycho-existential framework to reveal what may have motivated Baum to write the first $\mathrm{Oz}$ installment).

151 See generally Alice Miller, The Body Never Lies: The LINGERING EFFECTS OF HURTFUl PARENTING (Andrew Jenkins trans., 2005) (2004) (analyzing how repressed emotional responses to early humiliations and unfulfilled needs are transmitted to the body and can produce long-term illness).

152 See generally id.

153 See generally MiLLER, FreE From LIES, supra note 37, at 45-89 (arguing that destructive actions against children are the vehicles through which evil enters our world because those abused children can grow up to repeat their trauma on other human beings).

${ }^{154}$ Miller, BANisHed KNOWLEDGE, supra note 10, at 46. 
consciously wished to hurt or harm Precious. In talking to Ms. Weiss, Mary told her now she cared for Precious, taking out in even in cold weather for fresh air, dressing her in pink, and taking care to dress her in "little pink bootie socks."155 Unfortunately, Mary repressed much of her early pain, lest it would have more than likely killed her. Accordingly, Miller states: "What can a child do when she is left so utterly alone with her panic, her impotent fury, her despair and anguish? The child must not even cry, much less scream, if she doesn't want to be killed. The only way she can get rid of these emotions is to repress them."156 Miller's view on repression applies during slavery, which was observed by Laura Towne. She described black children who were required to love and obey their parents, even though they were humiliated, silenced, and beaten harshly and regularly. ${ }^{157}$ They too were innocent and impotent. They had no voice; at least none that mattered. Complaining subjected them to stinging humiliation. How could they love?158 How would they care

155 SAPPhIRE, supra note 1, at 134.
156 Miller, BANISHED KNOWLEDGE, supra note 10, at 40.
157 See GUTMAN, supra note 96, at 219-20.
158 See, e.g., Reva B. Siegel, "The Rule of Love": Wife Beating as Prerogative and Privacy, 105 YALE L.J. 2117, 2134-41 (1996) (illustrating that after slavery, black men were perhaps generally beating their black female wives, but also suggesting that prosecutors were motivated to convict them due to racist concerns that blacks not enjoy the privileges that were normally enjoyed by white masters); $i d$. at 2139 n.85 ("Between 1889 and 1894, fifty-eight out of sixty men arrested for wifebeating in Charleston, South Carolina were black.") (citing Elizabeth Pleck, Wife Beating in Nineteenth-Century America, 4 Victimology 60, 65 (1979)); id. at 2139-40 n.85 ("debating bill to punish wife beaters in District of Columbia by flogging at whipping post and discussing committee report in support of bill that indicated that in the fourth precinct there were 14 white and 72 colored out of a total of 86 arrests for wife beating, and in the sixth precinct there were 23 white and 73 colored out of a total of 96 arrests for this offense' "), citing 40 CONG. REC. 2444, 2449 (1906) (remarks of Rep. Sims); LITWACK, supra note 97, at 349 (recalling her experiences shortly after emancipation, she stated: "Dat was the meanest niggah dat ever lived. He would slip up behin' me when I was wukin' in the fiel' an beat me."); $i d$. at 350 ("If I had a twenty-dollar bill this mornin for every time I seed my daddy beat up my mother and beat up my stepmother I wouldn't be settin here this morning because I'd have up in the hundreds of dollars."); Fulgham v. State, 46 Ala. 143 (1871) (upholding the assault and battery conviction of an emancipated slave for beating his emancipated wife after she interrupted him for what she thought was excessive corporal punishment on their child); Harris v. State, 14 So. 266 (Miss. 1894) (reversing and remanding conviction for assault with intent to kill of a black based on insufficient evidence). 
for their children, especially given the lack of love they experienced. 159

Unfortunately what Laura Towne observed during slavery was practiced during Jim Crow. In Genovese's Roll, Jordan, Roll, Ralph Ellison observed that to protect black children during Jim Crow, the

Southern Negro family's methods ... is the severe beating - a homeopathic dose of the violence generated by black and white relationships .... [H] ere the severe beating is administered by the mother, leaving the child no parental sanctuary. He must ever embrace violence along with maternal tenderness, or else reject, in his helpless way, the mother. . . ${ }^{160}$

To this extent, it would appear that repression and humiliation work indispensably with obedience training. Black parents then are literally requiring their children to swallow very powerful emotions, especially those that might suggest sassing or disrespect. Yet, repression numbs children, creating in the adult child potentially lethal personal and social consequences. On this point, Miller writes:

But repression is a perfidious fairy who will supply help at the moment but will eventually exact a price for this help. The impotent fury comes to life against when the girl's own child is born, and at last the anger can be discharged-once again at the expense of a defenseless creature. ${ }^{161}$

And so out of the maelstrom of abuse, assaults, and repression, Susan killed her infant daughter. Carl and Mary cocreated a relationship, undergirded by hurt, pain, anger, and impotence that must have surrounded their sexual abuse as children. Given that Mary declared that she was a good mother, she, like Carl, must have deeply repressed their sexual abuse, which directly impacted Precious' life. Likewise, given her word to Ms. Weiss,

159 See Miller, BANISHED KNOWLEDGE, supra note 10 , at 40 ("When such a child must consume all her capability and energy for the required labor of repression; when, in addition, she has never known what it is to be loved and protected by someone, this child will eventually also be incapable of protecting herself and organizing her life in a meaningful and productive manner.").

160 Eugene D. Genovese, Roll, Jordan, Roll: The World THE SLAVES MADE 510 (1974).

161 Miller, BANISHED KNOWLEDGE, supra note 10, at 40. 
Mary subscribed unconsciously to cruelty as love. Together, they gave birth not to Precious but to an object onto which they could vent their impotent fury and discharge their anger. As they had been when they were children, Precious was impotent, innocent, and defenseless.

Except at Carl and Mary's brutal hands, Precious at no time knew of slavery, exploitation, humiliation, spiritually withering experiences, humiliation and disrespect. In this way, Precious differed only slightly from the black children who Laura Towne and Ralph Ellison described. In short, not slavery by white masters and overseers or alienating exploitation by an assembly line, but by black parents' unconscious need for obedient, near sycophant-like children can best explain why Carl and Mary brutally maltreated and sexually exploited Precious.

\section{CONCLUSION}

Hence, Miller's psycho-existentialism critiques the poisonous pedagogy, and through it, Miler would argue that Carl and Mary more than likely were both brutally exploited, including via sexual abuse. They assumed that they could best get love not through consent but through power. Thus, they could exploit an innocent, impotent child, and it was precisely these qualities that made Precious so sexually "gratifying." In so doing, Mary and Carl literally and symbolically recreated a living hell for Precious, thus arguably revealing the withering childhood through which they both suffered.

Accordingly, we cannot ignore that race consciousness and capitalist exploitation do not figure persuasively and predominantly into Precious' tragic biography. However, long before Precious knew of racism and worker exploitation, she learned that the world was cruel, brutal, violating, manipulative, arbitrary, and oppressive. Unfortunately, she did not learn these things from whites or greedy Wall Street financiers. Precious garnered these lessons from her parents, on whom she needed to rely for love and nurturance.

Yet, along the way, Precious needed to construct a socialized other, viz., "crackers," so that she could repress who actually hurt, beat, raped, and hated her. It is clear that Precious loved and hated Mary. She will point to how she was treated. She will recall that at "Each One Teach One," she learned to appreciate that only at home was she invisible. Unfortunately, her idea of visibility, acknowledgement, and appreciation was associated with 
white, skinny girls. Her mother and father never saw that she should be treated like the precious white girl she had internalized. In the end, Precious almost requires us, the reader, to hope for Precious that which she simply cannot have unless she can fault not whites and racism but Carl and Mary for her brutal maltreatment. 